Datokarama English Education Journal Vol.2 No. 2, 2021

\title{
THE IMPACT OF STUDENTS' MENTAL HEALTH IN ENGLISH ONLINE LEARNING DURING COVID-19 PANDEMIC AT SMA NEGERI 2 SOJOL
}

\author{
Lia Umi Mulyana \\ Muhammad Ihsan \\ Yuni Amelia \\ M. Tamrin AM. S. Pettawali \\ Study Program of English Tadris Faculty of Tarbiyah and Teacher Training \\ State Islamic University (UIN) Datokarama Palu \\ E-mail: liaaulia2149@gmail.com
}

\begin{abstract}
The global pandemic that set by the World Health Organization on January 30, 2020 as a result of the new disease of Covid-19 has made many major changes, one of them in education where learning system are done through online. Online learning policies during the Covid-19 pandemic are the main solution to keeping the learning process going. This thesis aims to find out what impact of English online learning has on students' mental health during the covid-19 pandemic at SMA Negeri 2 Sojol and To find out what factors hindered students in the process of English online learning at SMA Negeri 2 Sojol. In this research, the researcher applied a descriptive qualitative research which were located at SMA Negeri 2 Sojol. Data sources obtained through primary and secondary data. Data collection techniques used are questionnaire and interviews. Based on the results of the questioner showed that they tend to just felt bored, difficult to concentrate, feelings of fear or worry if they are unable to collect tasks on time as well as their difficulty in understanding the material when English online learning during the covid-19 pandemic. Where it is caused by several factors such as poor internet network, residential environment and also monotonous teaching techniques from English teachers.
\end{abstract}

Keyword : Impact, Mental Health, Online Learning, Covid-19 Pandemic. 
Datokarama English Education Journal Vol.2 No. 2, 2021

\section{Background}

Based on Law No. 20 of 2003 on The National Education System, it is explained that education is a conscious and planned effort to realize the atmosphere of learning and learning process so that students actively develop their potential to have the power of religious spirituality, selfcontrol, personality, intelligence, noble morals, as well as the necessary skills themselves, society, nation and country. ${ }^{1}$ To achieve a quality education, of course, it must be supported by a good learning process.

Generally, learning activities are carried out directly in a classroom, where educators and learners interact directly. However, since the covid-19 pandemic the government has taken steps by implementing an online learning system. It is known that the virus is identified as coming from Wuhan, Hubei Province, China.On January 30, 2020, WHO declared the Covid-19 as Public Health Emergency of International Concern (PHEIC). ${ }^{2}$

Online learning is an online learning system, using distance learning methods. According to Moore, et.al. Online learning is learning that uses the internet network with accessibility, connectivity, flexibility, and the ability to bring about different types of learning interactions. ${ }^{3}$ While Kuntarto stated Online learning is a learning that is

\footnotetext{
${ }^{1}$ Undang-Undang Republik Indonesia Nomor 23 Tahun 2003 Tentang Sistem Pendidikan Nasional.

${ }^{2}$ Kementerian Kesehatan RI dan Direktorat Jenderal Pencegahan dan Pengendalian Penyakit (P2P). Pedoman pencegahan dan pengendalian coronavirus disease (covid-19). Revisi ke-3, 2020.

${ }^{3}$ Joi, I. Moore. E-Learning, online learning, and distance learning environments: Are they the same? Internet and Higher Education,(2011), 14:129-135
}

able to bring together students and lecturers to carry out learning interactions with the help of the internet. ${ }^{4}$

Although online learning is currently the solution of the education system during the covid-19 pandemic, in fact there are still many obstacles and shortcomings in its implementation. Online learning requires students to have the ability to master technology as a learning media, students must also be ready to face various obstacles in carrying out lectures online such as network problems, the state of servers or devices used are often problematic, internet quotas are used also not a little.

In addition to having to focus on adapting in this learning system, students also need to maintain physical and mental health because so far not a few students are experiencing stress because they are not able to attend online lectures properly due to various obstacles in undergoing and receiving lecture materials because each student has different thoughts and knowledge.

This online learning restricts children from social activities and interactions, resulting in a poor impact on children's education and development. ${ }^{5}$ Mekonnen, et al. mention that one of the very important aspects in a child's development is mental health. ${ }^{6}$

\footnotetext{
${ }^{4}$ Eko Kuntarto, Keefektifan Model

Pembelajaran Daring dalam Perkuliahan Bahasa

Indonesia di Perguruan Tinggi. Indonesian Language Education and Literature, 3(1), 99-110, (2017)

${ }^{5}$ Siti Fatimah dan Umi Mahmudah. How ELearning Affects Students' Mental Health During Covid-19 Pandemic: An Empirical Study. Universitas Sebelas Maret, Pekalongan.2020.

${ }^{6}$ Habtamu Menkonnen, et.al. Impact Of Child Emotional And Behavioural Difculties On Educational Outcomes Of Primary School Children In Ethiopia: a Population-Based Cohort Study. Child
} 
Datokarama English Education Journal Vol.2 No. 2, 2021

Mental health is a key component in a child's healthy development; children need to be healthy in order to learn, grow, and lead productive lives. ${ }^{7}$ Mental health includes the emotional, psychological, and social well-being of each individual. It affects the way you think, feel, and act. Mental health also helps determine how to handle stress, connect with others, and make choices. Mental health is important at every stage of life, from childhood and adolescence to adulthood. ${ }^{8}$

SMA Negeri 2 Sojol is one of the schools that implements the learning process through offline and online systems. English is one of the subjects that applies a learning model that utilizes online media and also one of the subjects to be teaching to students ranging from Elementary to college level. The Indonesian government began to introduce English as early as possible for students in primary schools through the 1994 Basic Education Curriculum. ${ }^{9}$

The implementation of learning through online media in the Covid-19 era at SMA Negeri 2 Sojol had an impact on students. Based on the result of pre-research conducted by the researcher at that school, the researcher found various impact of students when English online learning

Adolesc Psychiatry Ment Health. Vol. 14 (22): 1-10. 2020.

${ }^{7}$ Shannon Stagman dan Janice L. Cooper. Children's Mental Health What Every Policymaker Should Know. National Center for Children in Poverty (NCCP). 2010.

http://www.nccp.org/publications/ pdf/text_929.pdf

${ }^{8}$ Fadhli Rizal Makarim. Pentingnya jaga kesehatan mental sejak dini.2019.

https://www.halodoc.com/artikel/pentingnya -jaga-kesehatan-mental-sejak-dini, accessed 12 April 2021

${ }^{9}$ https://www.neliti.com/id/publications/290 612/pentingnya-pembelajaran-bahasa-inggris-disekolah\#id-section-content, accessed 23 March 2021. process. Some of students said that they often felt symptoms of headache, easily upset, bored and so on. This is due to learning techniques that were always monotonous during online learning.They tend become passive, difficult to understand the material and other symptoms.

To solve those problems, the English teacher should have variety ways and strategies in teaching trough online learning. The strategy which is used should be suitable to the students need, situation and condition such as in this covid-19 era. So that the aim of education would be reach effectively.

Therefore, based on the problems described above, the researcher conducted research entitled "The Impact of Students'Mental Health In English Online Learning During Covid-19 Pandemic at SMA Negeri 2 Sojol".

\section{Literature Review}

\subsection{Mental Health}

\section{Definition of Mental Health}

Generally, Health can be understood as full well-being (perfect state) both physically, mentally, and socially, not only free from disease or weak state. While in Indonesia, based on Law No. 23 / 1992 states that healthy is a state of physical, mental, and social health that allows every human being to live productively both socially and economically. The World Health Organization states that mental health is a condition of an individual's conscious well-being, in which there are the ability to manage the stress of a reasonable 
Datokarama English Education Journal Vol.2 No. 2, 2021

life, to work productively and produce, and to participate in their communities. ${ }^{10}$

A normal person / healthy mental is a person who displays strong behavior and acceptable to society in general, his attitude according to the norms / patterns of community groups, so that there are satisfactory interpersonal and intersocial relationships.Meanwhile, according to Karl Menninger in the mental health textbook by Kartika Sari dewi said thathealthy individuals are those who have the ability to restrain themselves, show intelligence, behave by stretching the feelings of others, and have a happy life attitude. Currently, mental health individuals can be defined in two sides, negatively with the absence of mental disorders and positively that is when the presence of characteristics of mental health individuals. ${ }^{11}$ The characteristics of mental health individuals refer to positive conditions or traits, such as: positive psychological well-being, strong character and good qualities / virtues. ${ }^{12}$

Moreover the paradigm used in studying Mental Health is believed to be a multifactorial review, among others:

a. Biological Approach

By studying brain function, endocrine glands, and sensory functions, the approach believes that an individual's mental

${ }^{10}$ Kartika Sari dewi. Buku Ajar Kesehatan Mental. Lembaga Pengembangan Dan Penjaminan Mutu Pendidikan Universitas Diponegoro Semarang, h. 10. 2012 .

${ }^{11}$ Ibid. 11.

${ }^{12}$ KateLowenthal.Religion, Culture, and Mental Health. New York: Cambridge University Press. 2006. health is strongly influenced by genetic and external factors.

\section{b. Psychological Approach}

The approach believes that psychological factors have a big effect on a person's mental state, where in the psychological approach has 3 large views that discuss about it, namely:

- Psychoanalysis

An approach that believes that individual interactions early in life as well as intrapsycholytic conflicts will affect a person's mental health development. Epigenetic factors study a person's psychological maturity that develops with physical growth in the stages of individual development, also a determining factor in an individual's mental health.

- Behavioristik

An approach that believes the learning process and social learning process will affect one's personality. Individual mistakes in the process of learning and social learning will result in mental disorders.

- Humanistik

The behavior of individuals is influenced by the hierarchy of needs that are possessed. In addition, the individual is believed to have the ability to understand his or her potential and develop to achieve selfactualization.

\section{c. Sosio-Cultural Approach}

Has several approaches, namely: Social Stratification that discusses socioeconomic factors and social selection; Social 
Datokarama English Education Journal Vol.2 No. 2, 2021

Interactions that discuss functions in an interpersonal relationship (Psychodynamic Theory, Theory of low social interaction: isolation, loneliness); Family Theory that studies the influence of parenting patterns, interactions between family members, and family functions on an individual's mental health: Social Change, which attributes long-term change, migration and industrialization, and crisis conditions to an individual's mental state; Socio-Cultural, which studies the influence of religion and culture on a person's mental state; Social Stressors, who studythe influence of various social situations that have a psychological impact (e.g. marriage, death, criminality, recession) on an individual's mental state.

\section{d. Environment Approach}

This approach has two dimensions: The Dimensions of the Physical Environment, which are related to: space, time, and the accompanying means (nutrition). Chemical and Biological Environmental Dimensions, associated with: pollution, radiation, viruses and bacteria, populations of other living things. ${ }^{13}$

\subsection{Online Learning}

Basically, Online learning is a distance learning. Distance learning system is a system that has been around since the middle of the 18th century. From the beginning, distance learning has always used technology for the implementation of its learning, ranging from the simplest technology to the latest. In short, the history of the development of distance learning can

\footnotetext{
${ }^{13}$ Kartika Sari dewi. Buku Ajar Kesehatan Mental. Lembaga Pengembangan Dan Penjaminan Mutu Pendidikan Universitas Diponegoro Semarang, h. 15-17. 2012.
}

be grouped based on the dominant technology it uses. ${ }^{14}$

Online Learning is A form of distance education in which a course or program is intentionally designed in advance to be delivered fully online. Faculty use pedagogical strategies for instruction, student engagement, and assessment that are specific to learning in a virtual environment. ${ }^{15}$

Online learning is a system that provides facilities to learn anytime and anywhere while still being to access the system. Without being limited by distance, space and time. The material has been provided in the system. Materials can be provided in verbal, visual, audio and motion forms. Onlinelearning was originally known for the influence of e-learning which was first introduced by the University of Illionis, which uses computer-based learning systems.

According to Learn Frame, Elearning is also called Technology-based Learning which is an education system that uses all electronic applications to support the teaching and learning process, including computer networks (Internet, Intranet, Satellite), electronic media (Audiou, TV, CD-ROM).

Moreover, Dabbagh and Ritlandstates that Online learning is an open and spread learning system using pedagogy devices (educational aids), which is possible through the internet and network-based technology to facilitate the formation of

\footnotetext{
${ }^{14}$ Tian Belawati, Pembelajaran Online, Edisi 2, Universitas Terbuka Kementerian Pendidikan dan kebudayaan. 2020.

${ }^{15}$ TonyBates.https://www.tonybates.ca/2016/ 07/15/online-learning-for-beginners-1-what-isonline-learning/, Accessed 13 January, 2021.
} 
Datokarama English Education Journal Vol.2 No. 2, 2021

learning processes and knowledge through meaningful action and action. ${ }^{16}$ Based on the definitions above, it can be concluded that online learning is a learning model that is done online without face-to-face by utilizing a network.

\subsection{Covid-19 Pandemic}

The Covid-19is an infectious disease caused by a newly discovered corona virus. ${ }^{17}$ Corona virus disease 2019 (Covid19) is defined as illness caused by a novel corona virus now called severe acute respiratory syndrome corona virus 2 (SARSCoV-2; formerly called 2019-nCoV), which was first identified amid an outbreak of respiratory illness cases in Wuhan, Hubei Province, China. It was initially reported to the WHO on December 31, 2019. On January 30, 2020, the WHO declared the covid-19 outbreak a global health emergency. On March 11, 2020, the WHO declared covid-19 a global pandemic, its first such designation since declaring H1N1 influenza a pandemic in 2009.

Illness caused by SARS-CoV-2 was termed covid-19 by the WHO, the acronym derived from "corona virus disease 2019". The name was chosen to avoid stigmatizing the virus's origins in terms of populations,

${ }^{16}$ AgengTriyono,https://www.haidunia.com/ pengertian-pembelajaran-online-menurut-ahli/, accessed 13 January 2021.

${ }^{17}$ World Health Organization. Coronavirus. https://www.who.int/health-

topics/coronavirus\#tab=tab_1, accessed 13 January 2021. geography, or animal associations. ${ }^{18}$ Corona virus is a large family of viruses that cause diseases ranging from mild to severe symptoms.

Corona virus Disease 2019 (Covid19) is a new type of disease that has never been identified before in humans. The covid-19 is zoonoses (transmitted between animals and humans). The research suggests that SARS is transmitted from civet cats to humans and MERS from camel to human. Meanwhile, animals that are the source of covid-19 transmission are still unknown. ${ }^{19}$

Early symptoms of Covid-19 infection can resemble flu symptoms, fever, runny nose, dry cough, sore throat, and headache. After that, symptoms can disappear and heal or even be severe. Sufferers with severe symptoms can experience high fever, cough with even bleeding, shortness of breath, and chest pain. These symptoms appear when the body reacts against the Covid-19.

Generally, there are 3 common symptoms that can indicate a person is infected with corona virus as follows:

- Fever (body temperature above 38 degrees Celsius)

- Dry cough

- Shortness of breath

In addition, there are several other symptoms that can also appear in Corona virus infection although it is rarer, namely:

\footnotetext{
${ }^{18}$ David J Cennimo et. al., https://emedicine.medscape.com/article/2500114overview, accessed 13 January 2021.

${ }^{19}$ Kementerian Kesehatan RI \&Direktorat jenderal pencegahan dan penegendalian penyakit (P2P).,Pedoman pencegahan dan pengendalian coronavirus disease (covid-19. Revisi ke-3, 2020.
} 
Datokarama English Education Journal Vol.2 No. 2, 2021

- Diarrhea

- Headaches

- Conjunctivitis

- Loss of taste ability

- Loss of ability to smell (anosmia)

- Rash on the skin.

These symptoms of Covid-19 generally appear within 2 days to 2 weeks after the patient is exposed to coronavirus. Some patients infected with coronavirus may experience a decrease in oxygen without any symptoms. This condition is called happy hypoxia. ${ }^{20}$

\section{Methodology}

In this research the, the researcher used qualitative descriptive research methods. The researcher used a type of qualitative descriptive research that describes the aspects that are targeted by research. Therefore, the respondents of this research are students of SMAN 2 Sojol which consist of sixty students and also the English teacher. In this study, the data collected by the researcher was divided into 2 types, namely primer and secondary data. Then, the methods of data collection techniques that researcher applied are interview and questionnaire.

\section{Result and Discussion}

After knowing the results from questionnaire and interview, the researcher concluded that during English online learning in pandemic era, the students tend to just felt bored, difficult to concentrate, difficulty in understanding the material, and feelings of fear or worry if they are unable to collect tasks on time. Where it is caused by several factors such as poor internet network, residential environment and also

${ }^{20} \mathrm{https}$ ///www.alodokter.com/virus-corona , accessed 13 January 2021 monotonous teaching techniques from English teacher.

\section{Conclusion and Suggestion}

\subsection{Conclusion}

A psychologist for children, teenagers and families, said there are many causes that students' mental health can be impaired during distance learning. For example, losing everyday moments such as chatting with friends, feeling isolated, feeling frustrated because of quota signal problems, academic burdens, not being able to understand the material and so on. ${ }^{21}$

Based on the previous discussion and the result of the research, the researcher would make conclusion by showing the result of questionnaire and interview. The researcher concluded that during English online learning in pandemic era, the students tend to just felt bored, difficult to concentrate, difficulty in understanding the material, and feelings of fear or worry if they are unable to collect tasks on time. Where it is caused by several factors such as poor internet network, residential environment and also monotonous teaching techniques from English teacher.

\subsection{Suggestion}

The constructive advice that the researcher can convey based on the problems that have been discussed related to the impact of students' mental health in English online learning during covid-19 pandemic at students of SMA Negeri 2 Sojol are as follows:

\footnotetext{
${ }^{21}$ Jovina Maria. Psikolog: Jaga Kesehatan Mental saat PJJ dengan 8 Cara. https://amp-kompascom.ampproject.org
} 
Datokarama English Education Journal Vol.2 No. 2, 2021

1. Teachers should be aware of students' mental health when English online learning especially in the event of a pandemic situation. In addition, teachers should also pay attention to strategies in the teaching process, so as not to make the monotonous learning process.

2. Parents should also be able to monitor the learning process of children at home and give affection to their children, in order to avoid disturbing causes of mental health, so as to motivate children to be able to learn well.

3. Students are expected to know the importance of maintaining mental health, starting from knowing the signs of health disorders and how to maintain good and correct mental health. 
Datokarama English Education Journal Vol.2 No. 2, 2021

\section{References}

Bates,Tony.https://www.tonybates.ca/2016/ 07/15/online-learning-for-beginners1-what-is-online-learning/, accessed 13 January, 2021.

Belawati, Tian. Pembelajaran Online, Edisi 2, Universitas Terbuka Kementerian Pendidikan dan kebudayaan, 2020.

Cennimo, David J, et. al., https://emedicine.medscape.com/arti cle/2500114-overview, accessed 13 January 2021.

Dewi, Kartika Sari. Buku Ajar Kesehatan Mental. Lembaga Pengembangan Dan Penjaminan Mutu Pendidikan Universitas Diponegoro Semarang, h.10. 2012.

Dewi, Kartika Sari. Buku Ajar Kesehatan Mental. Lembaga Pengembangan Dan Penjaminan Mutu Pendidikan Universitas Diponegoro Semarang, h. 11. 2012.

Dewi, Kartika Sari. Buku Ajar Kesehatan Mental. Lembaga Pengembangan Dan Penjaminan Mutu Pendidikan Universitas Diponegoro Semarang, h. 15-17. 2012.

Fitria, Putri Ayu dan Desma Yuliadi Saputra.Dampak Pembelajaran Daring Terhadap Kesehatan Mental Mahasiswa Semester Awal.V.4.h.6066. 2020.

http://ciputrauceo.net/blog/2016/2/18/metod e-pengumpulan-data-dalampenelitian, accessed 13 January2021

https://www.alodokter.com/virus-corona, accessed 13 January 2021 https://www.neliti.com/id/publications/2906 12/pentingnya-pembelajaran-bahasainggris-di-sekolah\#id-sectioncontent, accessed 23 March 2021.

https://www.who.int/healthtopics/coronavirus\#tab=tab_1, Accessed 13 January 2021.

Kementerian Kesehatan RI dan Direktorat Jenderal Pencegahan dan Pengendalian Penyakit (P2P). Pedoman pencegahan dan pengendalian coronavirus disease (covid-19). Revisi ke-3, Jakarta: Kemkes, 2020.

Kuntarto, Eko. Keefektifan Model Pembelajaran Daring dalam Perkuliahan Bahasa Indonesia di Perguruan Tinggi. Indonesian Language Education and Literature, Vol. 3, No. 1, 99-110, 2017.

Lowenthal, Kate. Religion, Culture, and Mental Health. New York: Cambridge University Press. 2006.

Maria, Joviana. Psikolog: Jaga Kesehatan Mental saat PJJ dengan 8 Cara. https://amp-kompascom.ampproject.org

Makarim, Fadhli Rizal. Pentingnya jaga kesehatan mental sejak dini.2019.

https://www.halodoc.com/artikel/pentingnya -jaga-kesehatan-mental-sejak-dini, accessed 12 April 2021.

Margono, S. Penelitian Pendidikan. Jakarta:Rineka Putra Cipta, h. 38.2000 . 
Datokarama English Education Journal Vol.2 No. 2, 2021

Menkonnen, Habtamu, et.al. Impact Of Child Emotional And Behavioural Difculties On Educational Outcomes Of Primary School Children In Ethiopia: a PopulationBased Cohort Study. Child Adolesc Psychiatry Ment Health. Vol. 14 (22): 1-10. 2020.

Miles and Huberman, Qualitative Data Analysis: A Sourcebook of New Methods. Beverly Hills: Sage Publication, 1984, 23.

Moleong, Lexy J. Metode Penelitian Kualitatif. Bandung: Remaja Rosda Karya, 2004, 3.

Moleong, Lexy J., Metode Penelitian kualitatif. Bandung. Rosda Karya, 1990, 178.

Moleong, Lexy J., Metode Penelitian Kualitatif. Bandung: Remaja Rosda Karya, 12.

Moore, Joi. I. E-Learning, online learning, and distance learning environments: Are they the same? Internet and Higher Education, Vol. 14, 129-135, 2011.

Nur'azizah, Laily Yuniar, et. al. "Dampak Mental Bagi Siswa SDN Buaran Mangga II Akibat Pembelajaran Jarak Jauh.2021

Rezkia, Salsabila Miftah. https://www.dqlab.id/data-analisispahami-teknik-pengumpulan-data, accessed 14 January 2021.

Rianti, Dini. Kondisi Mental Mahasiswa Baru Menjalani Perkuliahan Online Pada Masa Pandemi.2020.
Rochimah., Fitria Amalia. Dampak Kuliah Daring Terhadap Kesehatan Mental Mahasiswa Ditinjau Dari Aspek Psikologi. Universitas Lambung Mangkurat.

Stagman, Shannon dan Janice L. Cooper. Children's Mental Health What Every Policymaker Should Know. National Center for Children in Poverty (NCCP). 2010.

http://www.nccp.org/publications/ pdf/text_929.pdf

Sudaryono. Metode penelitian. Jakarta: PT. Raja Grafindo Persada, 2017, 91.

Sudjana, Nana dan Ahwal Kusuma, Proposal Penelitian. Jakarta, 2000, 11.

Sudjana, Nana dan Awal Kusuma. Proposal penelitian di perguruan tinggi. Bandung: Sinar Baru Algnesindo, 2008, 84 .

Suryabrata, Sumadi. Metode Penelitian. Jakarta:PT.Raja Grafindo Persada,cet. ke-11,1998,18.

Syalwa, Ardita. Pembelajaran daring, efektif? https:www.kompasiana.com/arditasy alwa/5e7ba8d6097f36116506b8a2/p embelajaran-daring-efektif, accessed 13 January 2021.

Tohirin, Metode Penelitian Kualitatif Dalam Penelitian dan Bimbingan Konseling, Cet. 3; Jakarta: Raja Grafindo Persada, 2013, 76.

Tohirin, Metode Penelitian Kualitatif Dalam Penelitian dan Bimbingan Konseling, Cet. 3; Jakarta: Raja Grafindo Persada, 2013, 77. 
Datokarama English Education Journal Vol.2 No. 2, 2021

Triyono, Ageng.

https://www.haidunia.com/pengertia

n-pembelajaran-online-menurutahli/, accessed 13 January 2021

Undang-Undang Republik Indonesia Nomor 23 Tahun 2003 Tentang Sistem Pendidikan Nasional.

Wikipedia, Covid 19 Pandemic. https://en.wikipedia.org/wiki/COVID -19_pandemic, accessed 4 February 2021.

World Health Organization. Mental Health: Strengthening our Responses. 2018.

https://www.who.int/news-room/factsheets/detail/mental-healthstrengthening-our-response accessed 22 March 2021. 